\title{
Gametophytic self-incompatibility in Andean capuli (Prunus serotina subsp. capuli): allelic diversity at the S-RNase locus influences normal pollen-tube formation during fertilization
}

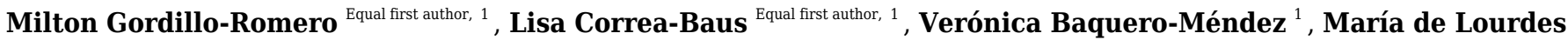 \\ Torres $^{1}$, Carlos Vintimilla ${ }^{1}$, Jose Tobar ${ }^{1}$, Andrés Torres ${ }^{\text {Corresp. } 1}$ \\ ${ }^{1}$ Laboratorio de Biotecnología Vegetal. Colegio de Ciencias Biológicas y Ambientales, Universidad San Francisco de Quito, Quito, Pichincha, Ecuador \\ Corresponding Author: Andrés Torres \\ Email address: atorres@usfq.edu.ec
}

Capuli (Prunus serotina subsp. capuli) is a tree species that is widely distributed in the northern Andes. In Prunus, fruit set and productivity appears to be limited by gametophytic self-incompatibility (GSI) which is controlled by the S-Locus. For the first time, this research reveals the molecular structure of the capuli S-RNase (a proxy for S-Locus diversity) and documents how S-Locus diversity influences GSI in the species. To this end, the capuli SRNase gene was amplified and sequenced in order to design a CAPS (Cleaved Amplified Polymorphic Sequence) marker system that could unequivocally detect S-alleles by targeting the highly polymorphic C2-C3 S-RNase intra-genic region. The devised system proved highly effective. When used to assess S-Locus diversity in $15 P$. serotina accessions, it could identify 18 S-alleles; 7 more than when using standard methodologies for the identification of S-alleles in Prunus species. CAPS marker information was subsequently used to formulate experimental crosses between compatible and incompatible individuals (as defined by their S-allelic identity). Crosses between heterozygote individuals with contrasting S-alleles resulted in normal pollen tube formation and growth. In crosses between individuals with exactly similar S-allele identities, pollen tubes often showed morphological alterations and arrested development, but for some (suspected) incompatible crosses, pollen tubes could reach the ovary. The latter indicates the possibility of a genotype-specific breakdown of GSI in the species. Overall, this supports the notion that S-Locus diversity influences the reproductive patterns of Andean capuli and that it should be considered in the design of orchards and basic propagation materials. 
1 Gametophytic self-incompatibility in Andean capuli (Prunus serotina subsp. 2 capuli): allelic diversity at the S-RNase locus influences normal pollen-tube 3 formation during fertilization

4

5 Milton Gordillo-Romero ${ }^{1 f}$, Lisa Correa-Baus ${ }^{11}$, Verónica Baquero-Méndez ${ }^{1}$, María de Lourdes

6 Torres $^{1}$, Carlos Vintimilla ${ }^{1}$, José Tobar ${ }^{1}$, Andrés F. Torres ${ }^{1}$

7

8 'Laboratorio de Biotecnología Vegetal, Colegio de Ciencias Biológicas y Ambientales, 9 Universidad San Francisco de Quito. Diego de Robles s/n y Vía Interoceánica, Quito-Ecuador.

10 I These authors contributed equally to the study

11

12 Corresponding Author:

13 Andrés F. Torres ${ }^{1}$

14 Email address: atorres@usfq.edu.ec 


\section{Abstract}

Capuli (Prunus serotina subsp. capuli) is a tree species that is widely distributed in the

northern Andes. In Prunus, fruit set and productivity appears to be limited by gametophytic self-incompatibility (GSI) which is controlled by the S-Locus. For the first time, this research reveals the molecular structure of the capuli S-RNase (a proxy for S-Locus diversity) and documents how S-Locus diversity influences GSI in the species. To this end, the capuli S-RNase gene was amplified and sequenced in order to design a CAPS (Cleaved Amplified Polymorphic Sequence) marker system that could unequivocally detect S-alleles by targeting the highly polymorphic C2-C3 S-RNase intra-genic region. The devised system proved highly effective. When used to assess S-Locus diversity in 15 P. serotina accessions, it could identify $18 \mathrm{~S}$ alleles; 7 more than when using standard methodologies for the identification of S-alleles in Prunus species. CAPS marker information was subsequently used to formulate experimental crosses between compatible and incompatible individuals (as defined by their S-allelic identity). Crosses between heterozygote individuals with contrasting S-alleles resulted in normal pollen tube formation and growth. In crosses between individuals with exactly similar S-allele identities, pollen tubes often showed morphological alterations and arrested development, but for some (suspected) incompatible crosses, pollen tubes could reach the ovary. The latter indicates the possibility of a genotype-specific breakdown of GSI in the species. Overall, this supports the notion that S-Locus diversity influences the reproductive patterns of Andean capuli and that it should be considered in the design of orchards and basic propagation materials. 
35

36

37

38

39

\section{Introduction}

The capuli (Prunus serotina subsp. capuli) is an allotetraploid woody perennial species, taxonomically positioned in a clade with the Padus and Laurocerasus sub-genera of the Prunus genus (Pairon et al., 2008; Bortiri et al., 2006; Guzmán et al., 2018). The species is native to North America, but has been naturalized in the Andean highlands of Colombia, Ecuador, Peru and Bolivia (Fresnedo-Ramírez et al., 2011; Guzmán et al., 2018). P. serotina was likely introduced in the 17th century during the Spanish colonization of South America and has since developed a rich ethnobotanical tradition in the region (Popenoe and Pachano 1922). Today, local communities of the Andes cultivate P. serotina for its sweet black drupes. These are used to produce traditional delicacies, ceremonial drinks and home-remedies (Popenoe and Pachano 1922).

P. serotina has the potential to contribute to the development of profitable, resilient and biodiverse farming systems in the high Andes. In addition to its palatable flavor, the capuli drupe possesses antimicrobial (Jiménez et al. 2011), antioxydant (Luna-Vázquez et al. 2013) and antiinflammatory properties (Vasco et al. 2009; Álvarez-Suárez et al. 2017). These characteristics make it an attractive product for health-food and nutraceutical markets. The export potential of the capuli fruit could serve as a socio-economic incentive towards the conservation, potentiation and utilization of this semi-domesticated species, while simultaneously improving rural livelihoods (National Research Council 1989).

The effective introduction of $P$. serotina in commercial orchards will require important interventions in genetics and agronomy. In particular, understanding the species' gametophytic self-incompatibility (GSI) system will prove crucial to the design of orchards that maximize fruit set and yields. GSI is a mechanism that has evolved to inhibit self-pollination and to restrict cross-pollination between genetically related individuals, thus preventing inbreeding depression 
59 while promoting heterozygosity (Ushijima et al. 1998; de Nettancourt 2001). In Prunus, GSI is 60 controlled by a single, multi-allelic locus (i.e. the S-Locus). The S-Locus is composed of two

61 independent genes that are tightly linked: the style-specific ribonuclease (S-RNase) and the S-

62 locus F-box protein (SFB). These genes respectively encode for the pistil and pollen specificity

63 factors of the self-incompatibility response (Tao and Iezzoni 2010). Individuals showing the

64 same S-haplotype (i.e., identical alleles for the S-RNase and SFB genes) belong to the same 65 incompatibility group (IG) and display cross-incompatibility. In numerous Prunus species, GSI

66 poses a restriction to free pollen flow and must be considered in the selection of cross-

67 compatible individuals to ensure fruit set in commercial orchards (Herrera et al. 2018). GSI can

68 also influence the selection of compatibility groups in breeding programs and seed multiplication

69 schemes (Cachi et al. 2017).

70 To our knowledge, GSI in P. serotina remains largely unexplored. Donovan (1969) studied

71 pollen extension and fruit-set patterns in selfings and crosses of North American $P$. serotina

72 populations. The results of this study provided support for GSI and some cross-incompatibility in

73 the species, but did not exclude the possibility for genotype-specific self-compatibility. At the

74 molecular level, Gordillo et al. (2015) investigated the allelic diversity of the S-Locus of Andean

75 P. serotina by evaluating the degree of polymorphic variation in the Intron-I region of the S-

76 RNase gene in 80 accessions from the Ecuadorian highlands. However, this study did not

77 evaluate if and how this molecular diversity controls GSI in the species. Therefore, the main

78 objective of this research was to study whether the P. serotina S-Locus controls sexual

79 incompatibility in the species. To this end, we characterized the molecular structure of the $P$.

80 serotina S-RNase gene in order to design an efficient molecular marker system that would enable

81 the analysis of the allelic diversity of the S-Locus in Andean capuli populations. Subsequently, 
82 S-allelic information was used to set-up experimental crosses between cross-compatible and

83 cross-incompatible haplotypes in order to evaluate pollen tube-formation patterns in-vivo.

84 Ultimately, we aimed to demonstrate that $P$. serotina individuals from the same IG exhibit

85 obstructed fertilization; the latter would support the notion that the S-Locus influences the 86 reproductive patterns of the species. 


\section{Materials \& Methods}

\section{Genetic and Plant Material}

89 The characterization of the P. serotina S-RNase gene and the development of a CAPS

90 (Cleaved Amplified Polymorphic Sequence) marker system were performed on a set of $15 P$.

91 serotina accessions for which S-RNase Intron-I polymorphisms had been previously described

92 (Gordillo et al. 2015). Leaf samples for these accessions were originally collected by Guadalupe

93 et al. (2015) from 6 provinces across the highlands of Ecuador. The geographical coordinates for

94 the collection site of each accession are detailed in Table S1. DNA samples for all 15 accessions

95 are stored at the Plant Biotechnology Laboratory of Universidad San Francisco de Quito

96 (Cumbayá, Ecuador) and were used in this investigation.

97 For pollination assays, we used an independent set of 7 capuli trees located in a private

98 orchard in Cayambe, Ecuador. These trees were selected because of their proximity to the Plant

99 Biotechnology Laboratory of Universidad San Francisco de Quito. For each individual tree, 100 genomic DNA was isolated from young leaves using the CTAB method (Xin and Chen 2006).

101 DNA concentration and quality were assessed by spectrophotometry using a Nanodrop 2000 102 spectrophotomer (Thermo Scientific).

\section{S-RNase gene amplification and DNA sequencing}

104 The amplification of the S-RNase gene of 15 P. serotina accessions previously studied by

105 Gordillo et al. (2015) was performed using the PaConsI-F

106 (MCTTGTTCTTGSTTTYGCTTTCTTC; Sonneveld et al. 2003) and EM-PC5consRD

107 (CAAAATACCACTTCATGTAACARC; Sutherland et al. 2004) primers. These primers

108 respectively target the Signal Peptide and C5 regions of the Prunus S-RNase gene. PCR

109 reactions consisted of 1X PCR Buffer (Invitrogen), $0.2 \mathrm{mM}$ dNTPs, $1.5 \mathrm{mM} \mathrm{MgCl} 2,0.3 \mu \mathrm{M}$ of 
110 each primer, $1 \mathrm{U}$ of Taq DNA polymerase (Invitrogen) and $40 \mathrm{ng}$ of DNA in a $25 \mu \mathrm{l}$ final

111 volume. Amplification conditions were as described by Ortega et al. (2006), but with a $58^{\circ} \mathrm{C}$

112 annealing temperature. Amplified products were separated by gel electrophoresis in 1.5\%

113 agarose gels at 80 volts for 90 minutes using TBE $1 \mathrm{X}$ as running buffer. DNA fragments were

114 visualized using SYBR-Safe (Invitrogen).

115 Finally, amplified products were excised from agarose gels and purified using the Wizard 116 SV Gel and PCR Clean-Up System Protocol (Promega). Purified products were subsequently

117 reamplified by PCR using the amplification conditions described above. Reamplified products

118 were sequenced at Macrogen Inc. (Seoul, Korea).

119 Analysis of the $\boldsymbol{P}$. serotina S-RNase sequences

120 Consensus nucleotide sequences from forward and reverse read of all amplified fragments 121 were obtained using PREGAP and GAP4 (Staden 1996). The search for homologous sequences 122 in the GenBank database was performed using the NCBI BLAST tool (Altschul et al. 1990).

123 Intraspecific and interspecific alignments were performed using the CLUSTAL W algorithm of 124 MEGA7 (Kumar et al. 2016). Deduced amino acid sequences were obtained by translating the 125 coding sequence corresponding to each of the alleles using the online ExPASY Tool (Gasteiger 126 et al. 2003). Alignments of the deduced amino acid sequences were performed using the

127 CLUSTAL Omega algorithm of the European Bioinformatics Institute (Madeira et al., 2019).

$128 \mathrm{Ka} / \mathrm{Ks}$ ratios calculation and the sliding window analysis with a window length of 20 codons 129 were performed using the DnaSp6 Software (Rozas and Rozas 1999). Shannon Entropy indexes 130 were calculated for each of the conserved regions $(\mathrm{C} 1, \mathrm{C} 2, \mathrm{C} 3, \mathrm{RC} 4)$ and the $\mathrm{RHV}$, using the 131 online Protein Variability Server (García-Boronat et al. 2008). 


\section{Design and validation of the CAPS marker system}

133 The CAPS marker system was designed in-silico using the Genome Compiler Software

134 Package (Amirav-Drory et al., 2015). The digest function was employed for the screening of

135 restriction sites located within the analyzed sequences using a pool of 100 available enzymes,

136 and the gel simulation function was employed for the visualization of the restriction patterns in

137 virtual gels after the in-silico digestions.

138 For the in-vitro validation of the developed CAPS marker system, we designed species

139 specific primers to amplify the C2-C3 intergenic region of the $P$. serotina $\mathrm{S}-\mathrm{RN}$ ase gene:

140 Ps1C2Fw (ATY-CAT-GGC-CTR-TGG-CCA-AG) and Ps2C3Rv (TGY-TTR-TTC-CAT-TCV-

141 CBT-TCC). Primer design was based on S-RNase full-length sequences produced in this study.

142 The C2-C3 regions of the 15 P. serotina accessions were amplified using the Ps1C2Fw/

143 Ps2C3Rv primers. Reagents concentrations for the PCR reaction were the following: 1X PCR

144 Buffer, $3 \mathrm{mM} \mathrm{MgCl}$, $0.2 \mathrm{mM}$ dNTPs, $0.5 \mu \mathrm{M}$ of each primer, Taq polymerase Platinum

145 (Invitrogen) $1 \mathrm{U}$ and $20 \mathrm{ng}$ of DNA in a $25 \mu \mathrm{l}$ final volume. Cycling conditions consisted in: 2

146 minutes of initial denaturation at $94^{\circ} \mathrm{C}$, followed by 35 cycles of 1 minute at $94^{\circ} \mathrm{C}, 2$ minutes at

$14758^{\circ} \mathrm{C}, 4$ minutes at $68^{\circ} \mathrm{C}$ and 10 minutes of final extension at $68^{\circ} \mathrm{C}$. PCR products were separated

148 by gel electrophoresis in $1.5 \%$ agarose gels. Running conditions were 80 volts for 90 minutes

149 using TBE $1 \mathrm{X}$ as running buffer. DNA fragments were visualized using SYBR-Safe

150 (Invitrogen). All the resulting bands were excised from the agarose gel and the DNA was

151 recovered using the Wizard® SV Gel and PCR Clean-Up System (Promega). Purified DNA was

152 reamplified using the same amplification conditions as described before, using $40 \mathrm{ng}$ of DNA as

153 template. Reamplified fragments were digested with RsaI, MboI, HinfI from the Anza line of

154 ThermoFisher Scientific. The digestion reactions consisted in individual digestions containing 9

$155 \mu \mathrm{l}$ of nuclease-free water, $2 \mu \mathrm{L}$ of digestion Buffer $10 \mathrm{X}, 1 \mu \mathrm{L}$ of enzyme and $8 \mu \mathrm{L}(<0.2 \mu \mathrm{g})$ of 
156 the reamplified fragments. Restriction reactions were incubated at $37^{\circ} \mathrm{C}$ for 20 minutes.

157 Restriction patterns were visualized by gel electrophoresis in $2 \%$ agarose gels. Running

158 conditions were 80 volts for 1 hour using TBE $1 \mathrm{X}$ as running buffer. DNA fragments were

159 visualized using SYBR-Safe (Invitrogen).

160

161

162

163

164

165

166

167

168

169

170

171

172

173

174

175

176

177

178

\section{Pollination Assays: pistil staining and analysis by fluorescence microscopy}

To evaluate whether S-Locus allelic variation influences self-incompatibility responses in $P$. serotina, we studied pollen tube formation and growth patterns in experimental crosses. Seven $P$. serotina trees at flowering stage were S-haplotyped using the CAPS marker system developed in this study. Based on S-haplotype results, we conducted incompatible crosses (i.e. selfpollinations or crosses between 2 heterozygote individuals carrying the exact same S-alleles) and compatible crosses (i.e. between heterozygotes presenting completely different S-alleles) by hand pollination in the laboratory. To this end, branches with flowers at stage 59 of the $\mathrm{BBCH}$ scale (Ramírez and Davenport 2016) were cut and transported to the Plant Biotechnology Laboratory of Universidad San Francisco de Quito and placed in water with plant food. To extract pollen from donor flowers, anthers were manually removed and dried for 24 hours at room temperature to facilitate adequate pollen release. Collected pollen was kept at $4{ }^{\circ} \mathrm{C}$ until further use. For pollination experiments, receptor flowers were emasculated and pollinated (invitro) using a paint brush 24 hours after emasculation. Per experimental cross, 25 pistils were collected 48 hours following hand pollination.

Subsequently, pollinated pistils were stained using the aniline blue protocol described by Jefferies and Belcher (1974), and pollen tube formation and extension patterns were analyzed via fluorescence microscopy. For the aniline blue staining protocol, pollinated pistils were fixed in $70 \%$ ethanol for 7 days. As preparation for microscopy, pistils were incubated at $62^{\circ} \mathrm{C}$ in $10 \mathrm{M}$ 
$179 \mathrm{NaOH}$ for $40 \mathrm{~min}$ to soften the tissue and to enhance staining. Softened pistils were washed in

180 distilled water and stained with aniline blue for 1 hour. Pollen tube extension patterns were

181 observed using a BX50 Fluorescent Microscope (Olympus). The Multiple Image Analysis

182 software package (Amscope) was used to obtain images of the style and for counting pollen

183 tubes. A total of 78 pistils were analyzed. All protocols were previously standardized specifically

184 for P. serotina subsp. capuli.

\section{Data analysis of pollen tubes growth assay}

In the style, pollen tube growth was scored as the number of pollen tubes that reached the

187 lower-third section of the style. To compare pollen tube growth and development in the different

188 type of crosses, the data was subjected to a normality test and to a Levene's test for assessing the

189 homocedasticity of the data. Subsequently, a one-way ANOVA was carried out and the means

190 were separated using the Fisher Pairwise comparisons, grouping information using the Fisher

191 LSD Method and 95\% of confidence. Analysis were performed using Minitab 17 Software

192 package (2010). 
193 Results

194 Molecular structure of the $P$. serotina S-RNase gene

195 In this study, we amplified, sequenced and characterized the S-RNase gene of 15 distinct $P$. 196 serotina accessions. The amplification process generated a total of 22 DNA fragments ranging in 197 size from 1023 to 2144 base pairs (Fig. S1). The identity of these 22 amplified fragments was 198 evaluated by comparing their Intron-I sequence with Intron-I sequences reported by Gordillo et 199 al. (2015). These comparisons revealed that 19 of the 22 amplicons corresponded to the 11 200 alleles previously described by Gordillo et al. (2015). The remaining 3 sequences were identified 201 as new S-RNase alleles. We adopted standard nomenclature rules to catalogue the 14 detected 202 alleles as $P$. serotina $\mathrm{S}_{1}-P$. serotina $\mathrm{S}_{14}$. DNA sequences for all identified alleles were 203 submitted to the NCBI GenBank database with the following accession numbers: MN098833204 MN098846 (Table S2).

Deduced amino acid sequences for 11 of the 14 identified $P$. serotina S-RNase alleles identified were aligned and compared amongst them (intraspecific comparisons), as well as with S-RNase sequences retrieved for other Prunus species (interspecific comparisons) (Fig. 1). coding sequences could be retrieved. Overall, intraspecific homologies ranged from $\sim 70 \%$ to $\sim 90 \%$, while interspecific homologies ranged from $\sim 81 \%$ to $\sim 99 \%$.

Furthermore, we confirmed that the $P$. serotina S-RNase gene exhibits the characteristic 212 molecular structure of Prunus T2/S-type RNases. When comparing the deduced amino acid 213 sequences of $P$. serotina S-RNases with S-RNases reported for other Prunus species, we were 214 able to identify the signal peptide region, Introns I and II, the five conserved regions and the 
215 hypervariable region located between C2 and C3 (Fig. 1). Shannon entropy indices $(H)$ were 216 employed to determine the degree of sequence variability for each of the gene's structural

217 regions amongst the 11 evaluated alleles. Our results indicated that the least variable regions 218 were $\mathrm{C} 1, \mathrm{C} 2$ and $\mathrm{C} 3(H=0.05,0.049$ and 0.09 , respectively), while the $\mathrm{RC} 4$ region presented a 219 higher variability index $(H=0.28)$. The $\mathrm{C} 5$ region was not included in the analysis as it 220 corresponded to the primer anchoring site (used for sequencing); therefore, its sequence could 221 not be retrieved. As anticipated, the most variable region was the $\mathrm{C} 2-\mathrm{C} 3$ intragenic region $(H$ $222=1.28$ ), containing the RHV region. Our results also indicated that the RHV sequence was unique 223 for each of the 11 examined S-RNase alleles (Fig. 1). In addition, $\mathrm{Ka} / \mathrm{Ks}$ ratios were used to 224 identify regions with a higher likelihood for the occurrence of non-synonymous mutations along 225 the S-RNase coding sequence. A sliding-window analysis of $\mathrm{Ka} / \mathrm{Ks}$ ratios for the 11 examined 226 alleles showed that the highest $\mathrm{Ka} / \mathrm{Ks}$ ratio (1.34) was located within the RHV region.

227 Conversely, the $\mathrm{C} 2$ and $\mathrm{C} 3$ regions showed the lowest $\mathrm{Ka} / \mathrm{Ks}$ ratios ( 0.37 and 0.17 , respectively) 228 (Fig. 2).

229 230

231 232 233 234 235

\section{Development of a CAPS marker system for analyzing the allelic diversity of the S-Locus in} P. serotina

Given its high degree polymorphism in size and sequence, the $\mathrm{C} 2-\mathrm{C} 3$ intragenic region was used as a target for the development of a CAPS (Cleaved Amplified Polymorphic Sequence) marker system for the identification of S-RNase alleles in P. serotina. The CAPS marker system entails the amplification of a specific DNA region followed by enzymatic restriction to generate unique and distinctive restriction patterns (Shavrukov 2016).

The design of the CAPS marker system was performed in-silico using the Genome Compiler Software Package. Sequences corresponding to the C2-C3 regions (isolated from full-length 
238 DNA sequences of the 11 S-RNase alleles) were screened using 100 restriction enzymes. From 239 these, we identified 9 restriction enzymes with the ability to cleave all or the majority $(>\sim 80 \%)$ 240 of the 11 sequences analyzed. Based on these results, 99 in-silico restrictions (11 alleles x 9 241 enzymes) were simulated and the digestion patterns were visualized using the virtual simulator 242 of Genome Compiler. These analyses demonstrated that to unequivocally identify the $11 \mathrm{~S}-$ 243 alleles, at least 3 restriction enzymes were necessary (RsaI, MboI, HinfI). Each of these enzymes 244 generated individual digestion patterns (Table 1) that when read simultaneously, produced a 245 unique fingerprint for each S-allele. Based on this selection of enzymes and the digestion 246 patterns, we generated a CAPS guide for the rapid identification of $P$. serotina S-RNase alleles 247 (Table 2).

In-silico results were then validated in-vitro by amplifying the C2-C3 region corresponding 249 to the 15 P. serotina accessions, followed by independent enzymatic restrictions with RsaI, MboI and HinfI. While the expectation was to obtain a maximum of 14 alleles for these 15 accessions

251 (based on DNA sequence analysis), 4 additional (unexpected) bands were obtained for 252 accessions H25, Azu15, Pic19, Car7, Car5, Car3, and Car12 during the C2-C3 amplification 253 (Fig. 3). After the enzymatic digestion, the restriction patterns of the already characterized alleles 254 matched with the in-silico predictions. Digestion patterns of the 4 unexpected bands did not 255 match with any of our in-silico predictions, therefore we presumed that these bands corresponded 256 to new uncharacterized S-alleles, which were designated as $\mathrm{S}_{15}-\mathrm{S}_{18}$. CAPS restriction patterns 257 corresponding to the $\mathrm{S}_{1}-\mathrm{S}_{18}$ alleles are presented in Fig. 4. 
259

260

261

262

263

264

265

266

267

268

269

270

271

272

273

274

275

276

277

278

279

280

281

282

\section{Influence of S-locus allelic variation on pollen tube formation patterns}

To evaluate whether S-Locus allelic variation influences self-incompatibility responses in $P$. serotina, we studied pollen tube formation and growth patterns in pollination experiments. To this end, we selected 7 P. serotina tress from a private orchard in Cayambe (Ecuador) based on their S-allelic composition (as revealed with our CAPS marker system). The 7 individuals, which were in full bloom and exhibited flowers at stage 59 of the BBHC scale, harbored 9 distinct Salleles. Six of these alleles had been previously characterized $\left(\mathrm{S}_{1}, \mathrm{~S}_{4}, \mathrm{~S}_{6}, \mathrm{~S}_{8}, \mathrm{~S}_{9}, \mathrm{~S}_{10}\right)$, but the remaining 3 patterns corresponded to new uncharacterized alleles; the latter were designated as $\mathrm{S}_{19}-\mathrm{S}_{21}$ (Table 3).

Based on these results, 2 types of crosses were established: incompatible crosses (i.e. selfpollinations or crosses between 2 heterozygote individuals carrying the exact same S-alleles) and compatible crosses (i.e. between heterozygote individuals presenting completely different Salleles). Crossing assays are summarized in Table 4. To evaluate incompatible and compatible responses, we analyzed pollen tube extension patterns via fluorescence microscopy. These results clearly indicated that pollen tubes develop differently depending on the type of cross (Fig. 5). In compatible crosses, we found pollen tubes that reached the ovary in all pollinated pistils (Fig. 5A). By contrast, in the pistils of incompatible crosses, pollen tube growth was typically inhibited in the upper- and middle-third sections of the style (Fig. 5B). Furthermore, pollen tubes in incompatible crosses showed swelling at the tip (Fig. 5C) - this morphological alteration was not observed in compatible crosses. For specific incompatible crosses, several pollinated pistils displayed a variable number of pollen tubes that reached the bottom-third section of the style, but in consistently lower proportions relative to compatible crosses (Table S3). The occurrence of this phenomenon was especially common in crosses $22 x 17$ and $17 x 17$. It is important to highlight, nevertheless, that pollen tubes that did reach the lower-third segment of the style in 
283 incompatible crosses always showed swollen tips. A one-way analysis of variance confirmed

284 that differences in pollen tube growth (based on arrested development vs. full development to 285 reach the ovary) between incompatible and compatible crosses were statistically significant at $286 \mathrm{p}<0.001$. 


\section{Discussion}

288 The S-RNase gene in $P$. serotina resembles those of related species

289 The main objective of this research was to elucidate whether the S-Locus of P. serotina

290 controls sexual incompatibility patterns in the species. To this end, we used the S-RNase gene as

291 a proxy for the identification of S-haplotypes in $P$. serotina and evaluated whether S-RNase

292 allelic diversity correlates with sexual incompatibility patterns.

293 Detailed analysis of the amino acid sequences of 11 P. serotina S-RNase alleles confirms

294 that the $P$. serotina S-RNase gene has a high degree of amino-acid sequence homology $(\sim 81 \%$ to 295 99\%) with stylar ribonucleases from related species Prunus (Ushijima et al. 1998; Yaegaki et 296 al. 2001; Vaughan et al. 2008; Gao et al. 2012). For instance, the P. serotina $S_{8}$ and $P$. webbii $S_{3}$ 297 (NCBI: ABY19368) alleles displayed a protein identity of $\sim 99 \%$ (Fig. S2). A high degree of 298 interspecific amino acid sequence homology between S-RNase alleles in Prunus has been 299 reported earlier (Banovic et al. 2009; Ortega et al. 2006; Surbanovski et al. 2007). These findings 300 support the hypothesis that Prunus S-alleles with very high interspecific identities (>99\%) may 301 have originated from a common ancestor before speciation, and that these alleles have been 302 conserved ever since in the derived lineages (Ortega et al. 2006; Surbanovski et al. 2007; Sassa 303 et al. 1996).

304 CAPS as a molecular marker for determining the allelic diversity of the S-Locus

305 To investigate GSI-controlled incompatibility patterns in P. serotina, we required an 306 effective marker system that would enable the unequivocal identification of S-RNase allelic 307 diversity. The standard methodology for S-alleles identification in Prunus species involves the 308 amplification of the S-RNase Intron I and Intron II, followed by amplicon size differentiation via 309 gel electrophoresis (Ortega et al. 2006; Sonneveld et al. 2003; Gao et al. 2012). However, this 
310 methodology often fails to discriminate between allelic variants exhibiting similar amplicon

311 length but distinct genetic sequences (Halász et al. 2008; Gordillo et al. 2015; Kodad et al. 2008;

312 López et al. 2004).

313 To address this limitation, we developed a CAPS molecular marker system designed to

314 identify sequence-level polymorphisms in the S-RNase C2-C3 intragenic region. This region was

315 selected as it includes the RHV sequence; the latter presumed to mediate the recognition of 316 genetically related S-RNase/SFB complexes (Matton et al. 1997; Ushijima et al. 1998). The

317 RHV region is located at the surface of the S-RNase protein and is thought to play a key role in 318 the recognition of self- and non self-pollen (Matton et al. 1997; Ushijima et al. 1998); it is

319 therefore considered an adequate proxy of the self-incompatibility response in P. serotina.

320 Furthermore, our results indicated that the $\mathrm{C} 2-\mathrm{C} 3$ intragenic region represents the most

321 polymorphic segment of the $P$. serotina S-RNase gene. In fact, Shannon entropy indices and

$322 \mathrm{Ka} / \mathrm{Ks}$ ratios revealed that the highest degree of amino acid sequence variation in the gene 323 concentrates in the RHV region.

324 The CAPS marker system designed in this study proved highly effective in the identification 325 of S-RNase alleles. When employed to genotype an initial core-set of 15 P. serotina accessions 326 representing a comprehensive sample of the species' S-RNase allelic diversity in the Ecuadorian 327 highlands (Gordillo et al. 2015), the system enabled the unequivocal identification of $18 \mathrm{~S}-$ 328 RNase alleles. From these, seven alleles $\left(\mathrm{S}_{12}-\mathrm{S}_{18}\right)$ could not be identified when using the Intron I 329 molecular marker system (Gordillo et al. 2015), and four $\left(\mathrm{S}_{15}-\mathrm{S}_{18}\right)$ could not be detected when 330 amplifying, extracting and sequencing the full-length S-RNase genes for the aforementioned 15 331 individuals. Furthermore, an additional three alleles $\left(\mathrm{S}_{19}-\mathrm{S}_{21}\right)$ were identified when characterizing 332 a set of 7 individuals used for pollen-tube formation analyses. The effectiveness of our CAPS 
333 marker system in the determination of S-RNase diversity can be ascribed to three important

334 factors. In the first place, the use of species-specific primers to amplify the $\mathrm{C} 2-\mathrm{C} 3$ intragenic

335 region allowed for a higher resolution and differentiation of length-based allelic variants. Size

336 differences in the $\mathrm{C} 2-\mathrm{C} 3$ intragenic region are attributable to differences in the lengths of the

337 Intron II and RHV sequences (i.e. the most polymorphic regions of the S-RNase gene) which are

338 easier to resolve via gel electrophoresis as low-molecular weight products. By contrast, the

339 amplification of the full-length S-RNases yield high-molecular weight amplicons of similar size

340 which are not easily isolated. The inability to purify these amplicons independently may lead to

341 the masking-off of allelic differences resulting in allele-misidentification during sequencing (i.e.

342 pooling of two or more allelic variants yields one consensus sequence as seen in this study). In

343 second place, the use of 3 restriction enzymes is a powerful tool to exploit and elucidate the

344 intrinsic, polymorphic nature of the $\mathrm{C} 2-\mathrm{C} 3$ intragenic region. This feature is especially useful

345 when two S-alleles exhibit similar amplicon lengths (i.e. gel electrophoresis does not allow the

346 clear resolution of size-differences of a few base pairs). Accordingly, it offers an opportunity to

347 identify heterozygotes when an individual's S-alleles are similar in sequence length (Moriya et

348 al. 2007). Finally, the in-silico design of our CAPS molecular system allowed us the possibility

349 to simulate multiple digestions in order to identify the most informative restriction enzymes. The

350 efficiency of our 3 enzyme CAPS marker system is evident when comparing it to CAPS systems

351 developed for haplotyping the S-Locus in other species from the Rosacea family. For instance,

352 for the identification of 17 S-alleles in European pear cultivars it was necessary to employ 11

353 different enzymes (Moriya et al. 2007), whereas for the identification of 22 S-alleles in Japanese

354 apple cultivars, 17 different enzymes were required (Kim et al. 2008). 
355 S-Locus allelic diversity and its influence over GSI in P. serotina

356

357

358

359

360

361

362

363

364

365

366

367

368

369

370

371

372

373

374

375

376

377

378

As evidenced in this study, the S-RNase of $P$. serotina shares a high degree of identity with S-RNases from related species for which the S-Locus has been reported to control GSI. This finding would suggest that the S-Locus also plays a crucial role in determining the reproductive patterns of $P$. serotina. To add evidence to this theory, we investigated pollen-tube formation in crosses between compatible and incompatible individuals (as defined by their S-allelic composition via CAPS).

Our results demonstrated that crosses between heterozygote individuals with contrasting Salleles result in normal pollen tube formation and growth (i.e. pollen tubes extend along the style and reach the ovary). In these crosses, the number of pollen tubes reaching the ovary was abundant. By contrast, in pistils from crosses between heterozygote individuals with exactly similar S-allele identities (including self-pollinations), the vast majority of pollen tubes showed morphological alterations (i.e. swelling of pollen tube tips) and arrested development (Fig. 5). In a number of incompatible crosses, a variable number of pollen tubes could reach the lower-third section of the style, albeit at a comparatively lower density than in compatible crosses. These pollen tubes also showed swollen tips, a morphological alteration that is caracteristic of aberrant pollen tubes (Oukabli et al. 2000; Ludwig et al. 2013; Cachi et al. 2014; Estaji et al. 2016; Radunić et al. 2017). For two specific incompatible crosses (i.e. $22 x 17$ and 17x17), however, a substantial number of pollen tubes could reach the ovary. This unexpected result could be evidence of a full or partial breakdown of the P. serotina GSI system.

The breakdown of GSI is not an uncommon phenomenon in Prunus (Yamane et al. 2001; Hauck et al. 2002; Tobutt et al. 2004; Zarrinbal et al. 2018; Guerra et al. 2019). In fact, in a previous investigation of GSI in P. serotina, Donovan (1969) reported that selfings of specific genotypes led to normal fertilization, embryo formation and fruit set. Donovan (1969) concluded 
379 that the incompatibility reaction in P. serotina was not as strong as in other members of the 380 genus, and the author could not rule out self-compatibility in the species. In other Prunus 381 species, the partial or full loss of self-incompatibility has been primarily ascribed to the presence 382 of non-functional S-haplotypes caused by mutations in the S-RNase (Hauck et al.2002; Hauck et 383 al. 2006; Li et al. 2020) or SFB genes (Wünsch and Hormaza 2004; Tao et al. 2007; Wu et al.

384 2013; Muñoz-Espinoza et al.2017) that lead to loss of functionality. In this study, we have 385 focused exclusively on investigating the phenotypic behavior of pollen tube formation patterns in 386 compatible and incompatible crosses using S-RNase diversity as proxy for S-Locus identity.

387 However, GSI in Prunus is attributed to the interaction and recognition of self/non-self S388 RNase/SFB complexes (Matsumoto and Tao 2016), and a clearer understanding of GSI and self389 compatibility in $P$. serotina will also require a profound investigation of SFB diversity.

390 Furthermore, a concise understanding of the extent of GSI in P. serotina, and the extent to which

391 the S-Locus influences the reproductive patterns of the species, will also need to explored and 392 validated with fertilization and fruit set experiments in vivo. 


\section{Conclusions}

394 In this study, our objective was to investigate if the P. serotina S-Locus controls

395 gemetophytic sexual incompatibility (GSI) in the species. To this end, we characterized the 396 molecular structure of the $P$. serotina S-RNase gene and developed a CAPS molecular marker 397 system to unequivocally determine S-RNase alleles. Experimental crosses between cross398 compatible and cross-incompatible S-haplotypes (as determined by CAPS) were then used to 399 evaluate pollen tube-formation patterns in-vivo. Our results demonstrate that crosses between 400 heterozygote individuals with contrasting S-haplotypes result in normal pollen tube formation 401 and growth (i.e. pollen tubes extend along the style and reach the ovary). Accordingly, crosses 402 between individuals with the same S-haplotype typically lead to the morphological alteration of 403 pollen tubes and arrested development during fertilization. Notwithstanding, we also report that 404 some (suspected) incompatible crosses, pollen tubes can reach the ovary. The latter hints at the 405 possibility of genotype-specific breakdown of GSI in the species. 


\section{Acknowledgements}

407 The authors would like to acknowledge the technical assistance offered by researchers at the

408 Plant Biotechnology Laboratory (COCIBA, USFQ), as well as Dr. Pieter van 't Hof for his

409 technical assistance in the initial stages of this research project. 
410 References

411 Altschul SF, Gish W, Miller W, Myers EW, Lipman DJ (1990). Basic local alignment search

412

413

414

415

416

417

418

419

420

421

422

423

424

425

426

427

428

429

430

431

432

433

434

435

436

437

438

439

440

441

442

443

444

445

446

447

448

449

450 tool. Journal of Molecular Biology 215: 403-410. https://doi.org/10.1016/S00222836(05)80360-2

Álvarez-Suárez JM, Carrillo-Perdomo E, Aller A, Giampieri F, Gasparrini M, González-Pérez L, Beltrán-Ayala P, Battino M (2017) Anti-inflammatory effect of Capuli cherry against LPSinduced cytotoxic damage in RAW 264.7 macrophages. Food Chem Toxicol 102:46-52. https://doi:10.1016/j.fct.2017.01.024

Amirav-Drory O, Debbi Y, Nevo R (2015) Genome Compiler. http://www.genomecompiler.com (last viewed 2019-06-25)

Banovic B, Surbanovski N, Konstantinovic M, Maksimovic V (2009) Basic RNases of wild almond (Prunus webbii): cloning and characterization of six new S-RNase and one "nonS RNase" genes. J Plant Physiol 166:395-402. https://doi:10.1016/j.jplph.2008.06.009

Bortiri E, Vanden B, Potter D (2006) Phylogenetic analysis of morphology in Prunus reveals extensive homoplasy. Plant Systematics and Evolution 259: 53-71. https://doi.org/10.1007/s00606-006-0427-8

Cachi AM, Hedhly A, Hormaza JI, Wünsch A (2014) Pollen tube growth in the self-compatible sweet cherry genotype, 'Cristobalina', is slowed down after self pollination: Pollen tube growth in self-compatible cherry. Annals of Applied Biology 64: 73-84. https://doi.org/10.1111/aab.12079

Cachi AM, Wünsch A, Vilanova A, Guàrdia M, Ciordia M, Aletà N, Flachowsky H (2017) Slocus diversity and cross-compatibility of wild Prunus avium for timber breeding. Plant Breeding 136:126-131. https://doi:10.1111/pbr.12450

de Nettancourt, D. 2001. Incompability and incongruity in wild and cultivated plants. Springer, Berlin

Donovan C (1969) Self and Cross-incompatibility in Black Cherry (Prunus serotina). $\mathrm{PhD}$ Thesis. The University of Florida

Estaji A, Ebadi A, Ghorbani A, Allabakhsh R (2016) Comparison of different classical and molecular methods to identify superior self-compatible almond (Prunus dulcis Mill.) genotypes and evaluation of their traits. The Journal of Horticultural Science and Biotechnology 91: 36-42. https://doi.org/10.1080/14620316.2015.1110990

Fresnedo-Ramírez J, Segura S, Muratalla-Lúa A (2011) Morphovariability of capulín (Prunus serotina Ehrh, in the central-western region of Mexico from a plant genetic resources perspective. Genetic Resources and Crop Evolution 58: 481-495. https://doi.org/10.1007/s10722-010-9592-2

Gao Z, Wang P, Zhuang W, Zhang Z (2012) Sequence Analysis of New S-RNase and SFB alleles in Japanese Apricot (Prunus mume). Plant Molecular Biology Reporter 31:751762. https://doi:10.1007/s11105-012-0535-2

García-Boronat M, Diez-Rivero C, Reinherz E, Reche P (2008) PVS: a web server for protein sequence variability analysis tuned to facilitate conserved epitope discovery. Nucleic Acids Res 36:W35-41 
451 Gasteiger E, Gattiker A, Hoogland C, Ivanyi I, Appel RD, Bairoch A (2003) ExPASy: The

452

453

454

455

456

457

458

459

460

461

462

463

464

465

466

467

468

469

470

471

472

473

474

475

476

477

478

479

480

481

482

483

484

485

486

487

488

489

490 proteomics server for in-depth protein knowledge and analysis. Nucleic Acids Res 31:3784-3788. https://doi:10.1093/nar/gkg563

Gordillo M, Tobar J, ArahanaV, Torres ML (2015) Identification of S alleles associated with self-incompatibility in capuli (Prunus serotina) Avances en Ciencias e Ingenierías 7: B17-B23

Guadalupe JJ, Gutiérrez B, Intriago-Baldeón DP, Arahana V, Tobar J, Torres AF, Torres MdL (2015) Genetic diversity and distribution patterns of Ecuadorian capuli (Prunus serotina). Biochemical Systematics and Ecology 60:67-73. https://doi:10.1016/j.bse.2015.04.001

Guerra ME, Guerrero BI, Casadomet C, Rodrigo J (2020) Self-(in)compatibility, S-RNase allele identification, and selection of pollinizers in new Japanese plum-type cultivars. Scientia Horticulturae, 261(November). https://doi.org/10.1016/j.scienta.2019.109022

Guzmán FA, Segura S, Aradhya M, Potter D (2018) Evaluation of the genetic structure present in natural populations of four subspecies of black cherry (Prunus serotina Ehrh) from North America using SSR markers. Scientia Horticulturae 232: 206-215. https://doi.org/10.1016/j.scienta.2018.01.013

Halász J, Fodor Á, Hegedűs A, Pedryc A (2008) Identification of a new self-incompatibility allele (S31) in a Hungarian almond cultivar and its reliable detection. Scientia Horticulturae 116:448-451. https://doi:10.1016/j.scienta.2008.02.009

Hauck NR, Yamane H, Tao R, Iezzoni AF (2002) Self-compatibility and incompatibility in tetraploid sour cherry (Prunus cerasus L.). Sexual Plant Reproduction 15: 39-46. https://doi.org/10.1007/s00497-002-0136-6

Hauck NR, Yamane H, Tao R, Iezzoni AF (2006) Accumulation of nonfunctional S-haplotypes results in the breakdown of gametophytic self-incompatibility in tetraploid Prunus. Genetics 172:1191-1198. https://doi:10.1534/genetics.105.049395

Herrera S, Lora J, Hormaza JI, Herrero M, Rodrigo J (2018) Optimizing Production in the New Generation of Apricot Cultivars: Self-incompatibility, S-RNase Allele Identification, and Incompatibility Group Assignment. Front Plant Sci 9:527. https://doi:10.3389/fpls.2018.00527

Jefferies CJ, Belcher AR (1974) A fluorescent brightener used for pollen tube identification in vivo Stain Technol., 49. pp. 199-202

Jiménez I, Castillo EA, Azuara E, Beristain C (2011). Actividad Antioxidante Y Antimicrobiana Del Capuli Rev. Mex. Ing. Quím 10:29-37

Kim H, Kakui H, Kotoda N, Hirata Y, Koba T, Sassa H (2008) Determination of partial genomic sequences and development of a CAPS system of the S-RNase gene for the identification of $22 \mathrm{~S}$ haplotypes of apple (Malus $\times$ domestica Borkh.). Molecular Breeding 23:463472. https://doi:10.1007/s11032-008-9249-4

Kodad O, Sánchez A, Saibo N, Oliveira M, Sociasi Company R (2008) Identification and characterization of new S-alleles associated with self-incompatibility in almond. Plant Breeding 127: 632-638. https://doi:10.1111/j.1439-0523.2008.01541.x 
491

492

493

494

495

496

497

498

499

500

501

502

503

504

505

506

507

508

509

510

511

512

513

514

515

516

517

518

519

520

521

522

523

524

525

526

527

528

529

530

531

Kumar S, Stecher G,Tamura K (2016) MEGA7: Molecular Evolutionary Genetics Analysis version 7.0. Molecular Biology and Evolution 33:1870-1874

Li Y, Wu J, Wu C, Yu J, Liu C, Fan W, Li W (2020) A mutation near the active site of S-RNase causes self-compatibility in S-RNase-based self-incompatible plants. Plant Molecular Biology 103: 129-139. https://doi.org/10.1007/s11103-020-00979-z

López M, Mnejja M, Rovira M, Collins G, Vargas FJ, Arus P, Batlle I (2004) Selfincompatibility genotypes in almond re-evaluated by PCR, stylar ribonucleases, sequencing analysis and controlled pollinations. Theor Appl Genet 109:954-964. https://doi:10.1007/s00122-004-1656-2

Ludwig S, Robertson A, Rich TCG, Djordjević M, Cerović R, Houston L, Hiscock SJ (2013) Breeding systems, hybridization and continuing evolution in Avon Gorge Sorbus. Annals of Botany 111: 563-575. https://doi: 10.1093/aob/mct013

Luna-Vázquez FJ et al. (2013) Nutraceutical value of black cherry Prunus serotina Ehrh. fruits: antioxidant and antihypertensive properties. Molecules 18:14597-14612. https://doi:10.3390/molecules 181214597

Madeira F, Park YM, Lee J, Buso N, Gur T, Madhusoodanan N (2019) The EMBL-EBI search and sequence analysis tools APIs in 2019. Nucleic Acids Res. 47(W1):W636-W641641.

Matsumoto D, Tao R (2016) Distinct Self-recognition in the Prunus S-RNase-based Gametophytic Self-incompatibility System. The Horticulture Journal 85:289-305. https://doi:10.2503/hortj.MI-IR06

Matton DP, Maes O, Laublin G, Xike Q, Bertrand C, Morse D, Cappadocia M (1997) Hypervariable domains of self-incompatibility RNases mediate allele-specific pollen recognition. Plant Cell 9:1757-1766. https://doi.org/10.1105/tpc.9.10.1757

Minitab Inc.. Minitab Reference Manual : Macintosh Version, Release 8. State College, PA:Minitab, 2010.

Moriya Y, Yamamoto K, Okada K, Iwanami H, Bessho H, Nakanishi T, Takasaki T (2007) Development of a CAPS marker system for genotyping European pear cultivars harboring $17 \mathrm{~S}$ alleles. Plant Cell Rep 26:345-354.https://oi:10.1007/s00299-006-0254-y

Muñoz-Espinoza C, Espinosa E, Bascuñán R, Tapia S, Meneses C, Almeida AM (2017) Development of a molecular marker for self-compatible S4' haplotype in sweet cherry (Prunus avium L.) using high-resolution melting. Plant Breeding 136: 987-993. https://doi.org/10.1111/pbr.12546

National Research Council (1989) Lost Crops of the Incas: Little-Known Plants of the Andes with Promise for Worldwide Cultivation. Ruskin F(ed) Capuli Cherry, National Academies Press, Washington D.C, pp 223-227

Ortega E, Boskovic RI, Sargent DJ, Tobutt KR (2006) Analysis of S-RNase alleles of almond (Prunus dulcis): characterization of new sequences, resolution of synonyms and evidence of intragenic recombination. Mol Genet Genomics 276:413-426. https://doi:10.1007/s00438-006-0146-4

Oukabli A, Lansari A, Wallali DL, Abousalim A, Egea J, Michaux-Ferriere N (2000) Self and cross pollination effects on pollen tube growth and fertilization in self-compatible almond 
532

533

534

535

536

537

538

539

540

541

542

543

544

545

546

547

548

549

550

551

552

553

554

555

556

557

558

559

560

561

562

563

564

565

566

567

568

569

570

571 Tao R, Iezzoni AF (2010) The S-RNase-based gametophytic self-incompatibility system in Prunus

572

Prunus dulcis 'Tuono'. The Journal of Horticultural Science and Biotechnology 75: 739744. https://doi.org/10.1080/14620316.2000.11511316

Pairon M, Potter D, Jacquemart A (2008) Detection and characterization of genome-specific microsatellite markers in the allotetraploid Prunus serotina. Journal of the American Society for Horticultural Science 133: 390-395

Popenoe W, Pachano A (1922) The Capulin Cherry: A Superior Form of the Northern Black Cherry Developed in the Highlands of Tropical America. Journal of Heredity 13:51-62. https://doi:10.1093/oxfordjournals.jhered.a102156

Radunić M, Jazbec A, Ercisli S, Čmelik Z, Ban SG (2017) Pollen-pistil interaction influence the fruit set of sweet cherry. Scientia Horticulturae 224:358-366. http://dx.doi.org/10.1016/j.scienta.2017.06.010

Ramírez F, Davenport TL (2016) The phenology of the capuli cherry [Prunus serotina subsp. capuli (Cav.) McVaugh] characterized by the BBCH scale, landmark stages and implications for urban forestry in Bogotá, Colombia. Urban Forestry \& Urban Greening 19:202-211. https://doi:10.1016/j.ufug.2016.06.028

Rozas J, Rozas R (1999) DNASP version 3: an integrated program for molecular population genetics and molecular evolution analysis.Bioinformatics 15: 174-175.

Sassa H, Nishio T, Kowyama Y, Hirano H, Koba T, Ikehashi H (1996) Self-incompatibility (S) alleles of the Rosaceae encode members of a distinct class of the T2/S ribonuclease superfamily. Molecular and General Genetics 250: 547-557. https://doi.org/10.1007/s004380050108

Shavrukov YN (2016) CAPS markers in plant biology. Russian Journal of Genetics: Applied Research 6:279-287. https://doi:10.1134/s2079059716030114

Sonneveld T, Tobutt KR, Robbins TP (2003) Allele-specific PCR detection of sweet cherry selfincompatibility (S) alleles S1 to S16 using consensus and allele-specific primers. Theor Appl Genet 107:1059-1070. https://doi:10.1007/s00122-003-1274-4

Staden R. 1996. The Staden sequence analysis package. Molecular Biotechnology 5:233-241

Surbanovski N, Tobutt KR, Konstantinovic M, Maksimovic V, Sargent DJ, Stevanovic V, Boskovic RI (2007) Self-incompatibility of Prunus tenella and evidence that reproductively isolated species of Prunus have different SFB alleles coupled with an identical S-RNase allele. Plant J 50:723-734. https://doi:10.1111/j.1365313X.2007.03085.x

Sutherland BG, Robbins TP,Tobutt, KR (2004) Primers amplifying a range of Prunus S-alleles. Plant Breeding 123: 582-584.

Tao R, Watari A, Hanada T, Habu T, Yaegaki H, Yamaguchi M, Yamane H (2007) Selfcompatible peach (Prunus persica) has mutant versions of the $\mathrm{S}$ haplotypes found in selfincompatible Prunus species. Plant Molecular Biology 63: 109-123. https://doi.org/10.1007/s11103-006-9076-0 exhibits distinct genetic and molecular features. Scientia Horticulturae124:423-433. 
573

574

575

576

577

578

579

580

581

582

583

584

585

586

587

588

589

590

591

592

593

594

595

596

597

598

599

600

601

602

603

604

https://doi:10.1016/j.scienta.2010.01.025

Tobutt KR, Bošković R, Cerović R, Sonneveld T, Ružić D (2004) Identification of incompatibility alleles in the tetraploid species sour cherry. Theoretical and Applied Genetics 108: 775-785. https://doi.org/10.1007/s00122-003-1511-x

Ushijima K et al. (1998) Cloning and characterization of cDNAs encoding S-RNases from almond (Prunus dulcis): Primary structural features and sequence diversity of the SRNases in Rosaceae. Molecular and General Genetics 260: 261-268. https://doi.org/10.1007/s004380050894

Vasco C, Riihinen K, Ruales J, Kamal-Eldin A (2009) Phenolic Compounds in Rosaceae Fruits from Ecuador. Journal of Agricultural and Food Chemistry 57: 1204-1212. https://doi.org/10.1021/jf802656r

Vaughan SP, Bošković RI, Gisbert-Climent A, Russell K, Tobutt KR (2008) Characterisation of novel S-alleles from cherry (Prunus avium L.). Tree Genetics \& Genomes 4:531-541.

Wu J, Li M, Li T (2013) Genetic Features of the Spontaneous Self-Compatible Mutant, "Jin Zhui" (Pyrus bretschneideri Rehd.). PLoS ONE 8: e76509. https://doi.org/10.1371/journal.pone.0076509

Wünsch A, Hormaza JI (2004) Genetic and molecular analysis in Cristobalina sweet cherry, a spontaneous self-compatible mutant. Sexual Plant Reproduction 17: 203-210. https://doi.org/10.1007/s00497-004-0234-8

Xin Z, Chen J (2006) DNA Sequencing II Optimizing Preparation and Cleanup. Kieleczawa J (ed) Extraction of Genomic DNA from Plant Tissues, 2nd edn. Jones and Bartlett Publishers, Sudbury,pp. 49-50

Yaegaki H, Shimada T, Moriguchi T, Hayama H, Haji T, Yamaguchi M (2001) Molecular characterization of S-RNase genes and S-genotypes in the Japanese apricot (Prunus mume Sieb. et Zucc.). Sexual Plant Reproduction 13:251-257. https://doi.org/10.1007/s004970100064

Yamane H, Tao R, Sugiura A, Hauck NR, Iezzoni AF (2001) Identification and characterization of S-RNnases in tetraploid sour cherry (Prunus cerasus). Journal of the American Society for Horticultural Science 126: 661-667. https://doi.org/10.21273/jashs.126.6.661

Zarrinbal M, Soleimani A, Kohnehrouz BB, Dejampour J (2018) Self-compatibility in some apricot ( Prunus armeniaca L.) genotypes. Crop Breeding Journal 8: 49-59 


\section{Table 1 (on next page)}

Individual digestion patterns expected for the digestion of C2-C3 amplicons with three different enzymes (Rsal, Mbol and Hinfl).

Composed patterns (formed by the simultaneous reading of the three individual digestion patterns) specific to each S-allele are presented in Table 2. Note: In order to facilitate the digestion pattern identification, fragment sizes presented in this table were rounded. 
1

Restriction Enzymes

\begin{tabular}{|c|c|c|c|c|c|c|c|c|c|c|}
\hline Pattern & RsaI & & & Mbol & & & & Hinf & & \\
\hline A & 200 & & & 200 & & & & 180 & 100 & \\
\hline B & 200 & 160 & 150 & 210 & 200 & 190 & & 200 & & \\
\hline $\mathrm{C}$ & 210 & 140 & 100 & 240 & & & & 225 & 200 & \\
\hline D & 210 & 180 & 160 & 300 & & & & 230 & 190 & 100 \\
\hline $\mathrm{E}$ & 230 & 200 & & 300 & 100 & & & 240 & & \\
\hline F & 240 & & & 360 & & & & 250 & 210 & \\
\hline G & 240 & 225 & & 460 & & & & 360 & 250 & 220 \\
\hline $\mathrm{H}$ & 290 & 170 & 100 & 465 & 250 & 230 & & 365 & & \\
\hline I & 330 & 210 & 180 & 490 & & & & 375 & 330 & $250 \quad 210$ \\
\hline $\mathrm{J}$ & 370 & & & 520 & 430 & & & 380 & & \\
\hline K & 430 & 250 & & 550 & 415 & 250 & & 390 & 240 & \\
\hline $\mathrm{L}$ & 475 & 360 & 290 & 600 & 470 & 300 & & 470 & & \\
\hline M & 620 & 210 & $195 \quad 170$ & 615 & & & & 540 & & \\
\hline $\mathrm{N}$ & 790 & 510 & & 760 & & & & 550 & 495 & \\
\hline $\mathrm{O}$ & 940 & 220 & 170 & 1200 & & & & 550 & 350 & \\
\hline $\mathrm{P}$ & 950 & & & 290 & 180 & 100 & & 580 & & \\
\hline Q & 280 & 120 & 90 & 600 & 500 & 400 & 380 & 650 & 330 & 270 \\
\hline $\mathrm{R}$ & 220 & 200 & 110 & 430 & 100 & & & 290 & 220 & \\
\hline
\end{tabular}




\section{Table 2 (on next page)}

Composed digestion patterns for the identification of $P$. serotina $\mathrm{S}$-alleles $\left(\mathrm{S}_{1}-\mathrm{S}_{18}\right)$ using three restriction enzymes.

Each letter makes reference to the restriction pattern shown in Table 1 for each restriction enzyme (Rsal, Mbol and Hinfl, respectively). 
1

\begin{tabular}{c|c}
\hline $\begin{array}{c}\text { S-RNase } \\
\text { Allele }\end{array}$ & $\begin{array}{c}\text { Restriction } \\
\text { Pattern }\end{array}$ \\
S1 & PJN \\
S3 & BEJ \\
S4 & OLI \\
S5 & DFC \\
S6 & CIE \\
S7 & EGL \\
S8 & LHQ \\
S9 & IMK \\
S10 & KNJ \\
S12 & JFF \\
S13 & HCP \\
S14 & GBM \\
S15 & FCA \\
S16 & MKG \\
S17 & FCE \\
S18 & NOO \\
\hline & \\
\hline
\end{tabular}

2 


\section{Table 3 (on next page)}

S-allelic composition of the 7 P. serotina individuals selected for performing assisted crosses.

All individuals were heterozygotes and amplified 2 bands. S-alleles were determined using the CAPS marker system. 
1

\begin{tabular}{|c|c|c|c|c|c|}
\hline \multirow[b]{2}{*}{ Individual } & \multicolumn{4}{|c|}{ C2-C3 CAPS Patterns } & \multirow[b]{2}{*}{ S-allele } \\
\hline & Band & RsaI & MboI & HinfI & \\
\hline \multirow[t]{2}{*}{1} & 1 & $\mathrm{~L}$ & $\mathrm{H}$ & Q & $\mathrm{S}_{8}$ \\
\hline & 2 & Q & $\mathrm{P}$ & $\mathrm{R}$ & $\mathrm{S}_{19}$ \\
\hline \multirow[t]{2}{*}{12} & 1 & $\mathrm{O}$ & $\mathrm{L}$ & $\mathrm{I}$ & $\mathrm{S}_{4}$ \\
\hline & 2 & I & M & $\mathrm{K}$ & $\mathrm{S}_{9}$ \\
\hline \multirow[t]{2}{*}{13} & 1 & $\mathrm{O}$ & $\mathrm{L}$ & I & $\mathrm{S}_{4}$ \\
\hline & 2 & I & M & K & $\mathrm{S}_{9}$ \\
\hline \multirow[t]{2}{*}{14} & 1 & $\mathrm{O}$ & Q & $\mathrm{I}$ & $\mathrm{S}_{20}$ \\
\hline & 2 & $\mathrm{R}$ & $\mathrm{R}$ & $\mathrm{F}$ & $\mathrm{S}_{21}$ \\
\hline \multirow[t]{2}{*}{15} & 1 & $\mathrm{~K}$ & $\mathrm{~N}$ & $\mathrm{~J}$ & $\mathrm{~S}_{10}$ \\
\hline & 2 & $\mathrm{C}$ & $\mathrm{I}$ & $E$ & $\mathrm{~S}_{6}$ \\
\hline \multirow[t]{2}{*}{17} & 1 & $\mathrm{O}$ & $\mathrm{L}$ & $\mathrm{I}$ & $\mathrm{S}_{4}$ \\
\hline & 2 & $\mathrm{P}$ & $\mathrm{J}$ & $\mathrm{N}$ & $\mathrm{S}_{1}$ \\
\hline \multirow[t]{2}{*}{22} & 1 & $\mathrm{O}$ & $\mathrm{L}$ & I & $\mathrm{S}_{4}$ \\
\hline & 2 & $\mathrm{P}$ & $\mathrm{J}$ & $\mathrm{N}$ & $\mathrm{S}_{1}$ \\
\hline
\end{tabular}




\section{Table 4 (on next page)}

Proposed crosses according to the S-allelic composition of the 7 P. serotina trees genotyped.

Crosses between two individuals carrying the exact same S-alleles are expected to be incompatible. Crosses between two individuals carrying completely different S-alleles are expected to be compatible. Self-pollinations of the pollen receptor trees are expected to be incompatible. 
1

\begin{tabular}{ccccc}
\hline $\begin{array}{c}\text { Pollen } \\
\text { donor }\end{array}$ & $\begin{array}{c}\text { Pollen } \\
\text { Receptor }\end{array}$ & $\begin{array}{c}\text { Expected } \\
\text { phenotype }\end{array}$ & $\begin{array}{c}\text { Observed } \\
\text { phenotype }\end{array}$ \\
\hline $22\left(\mathrm{~S}_{1}, \mathrm{~S}_{4}\right)$ & $\mathrm{X}$ & $17\left(\mathrm{~S}_{1}, \mathrm{~S}_{4}\right)$ & Incompatible & Undetermined \\
\hline $12\left(\mathrm{~S}_{4}, \mathrm{~S}_{9}\right)$ & $\mathrm{X}$ & $13\left(\mathrm{~S}_{4}, \mathrm{~S}_{9}\right)$ & Incompatible & Incompatible \\
\hline $17\left(\mathrm{~S}_{1}, \mathrm{~S}_{4}\right)$ & $\mathrm{X}$ & $1\left(\mathrm{~S}_{8}, \mathrm{~S}_{19}\right)$ & Compatible & Compatible \\
\hline $14\left(\mathrm{~S}_{20}, \mathrm{~S}_{21}\right)$ & $\mathrm{X}$ & $15\left(\mathrm{~S}_{10}, \mathrm{~S}_{6}\right)$ & Compatible & Compatible \\
\hline $17\left(\mathrm{~S}_{1}, \mathrm{~S}_{4}\right)$ & $\mathrm{X}$ & $17\left(\mathrm{~S}_{1}, \mathrm{~S}_{4}\right)$ & Incompatible & Undetermined \\
\hline $13\left(\mathrm{~S}_{4}, \mathrm{~S}_{9}\right)$ & $\mathrm{X}$ & $13\left(\mathrm{~S}_{4}, \mathrm{~S}_{9}\right)$ & Incompatible & Incompatible \\
\hline $1\left(\mathrm{~S}_{8}, \mathrm{~S}_{19}\right)$ & $\mathrm{X}$ & $1\left(\mathrm{~S}_{8}, \mathrm{~S}_{19}\right)$ & Incompatible & Incompatible \\
\hline $15\left(\mathrm{~S}_{10}, \mathrm{~S}_{6}\right)$ & $\mathrm{X}$ & $15\left(\mathrm{~S}_{10}, \mathrm{~S}_{6}\right)$ & Incompatible & Incompatible
\end{tabular}

2 


\section{Figure 1}

Alignment of the deduced amino acid sequences of $P$. serotina S-RNases with S-RNases reported for different Prunus species.

Alignment included: P. serotina (capuli), P. tenella (dwarf Russian almond), P. armeniaca (apricot), P. salicina (plum), P. mume (Japanese apricot), P. avium (sweet cherry) for determining the genetic structure of the $P$. serotina S-RNase gene. Aligning algorithm: Clustal Omega (EMLB-EBI). Asterisks denote conserved sites; dots denote conservative substitutions and dashes indicate gaps. Conserved cysteine residues are pointed out with a filled circle, whereas conserved histidine residues are pointed out with an open circle. The signal peptide, the conserved (C1-C5) and the hyper-variable (RHV) regions are underlined. GenBank accession numbers: P. ten $S_{13}(K J 755355)$, P. sal $S_{c}(A B 084102)$, P. avi $S_{31}$ (DQ266443), P. arm $\mathrm{S}_{36}$ (GU574198), P. arm $\mathrm{S}_{1}$ (AY587561), P. arm $\mathrm{S}_{2}$ (AY587562), P. mum $\mathrm{S}_{1}$ (AB101438), P. mum $S_{7}(A B 364468)$, P. avi $S_{3}(A B 010306)$, P. sal $S_{a}(A B 252411), P$. dul $S_{c}(A B 011470)$

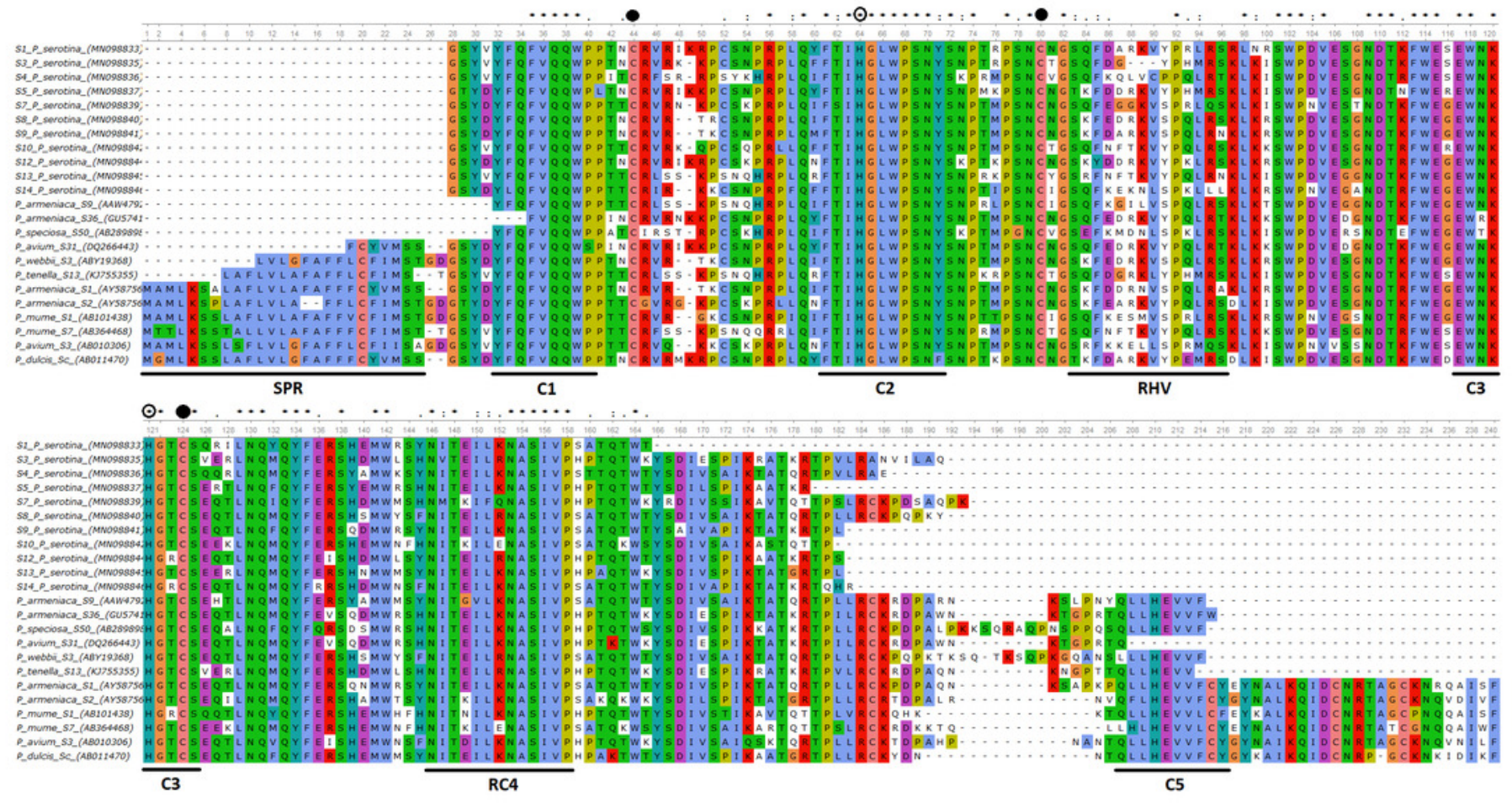


Figure 2

Graphical representation of the Ka/Ks ratios calculated along the coding sequence of the $11 P$. serotina S-alleles based on a sliding window analysis of 20 codons.

The position of conserved regions $(\mathrm{C} 1-\mathrm{C} 5)$ and $\mathrm{RHV}$ region are indicated. The plot was obtained using DnaSP6 (Rozas and Rozas 1999) 


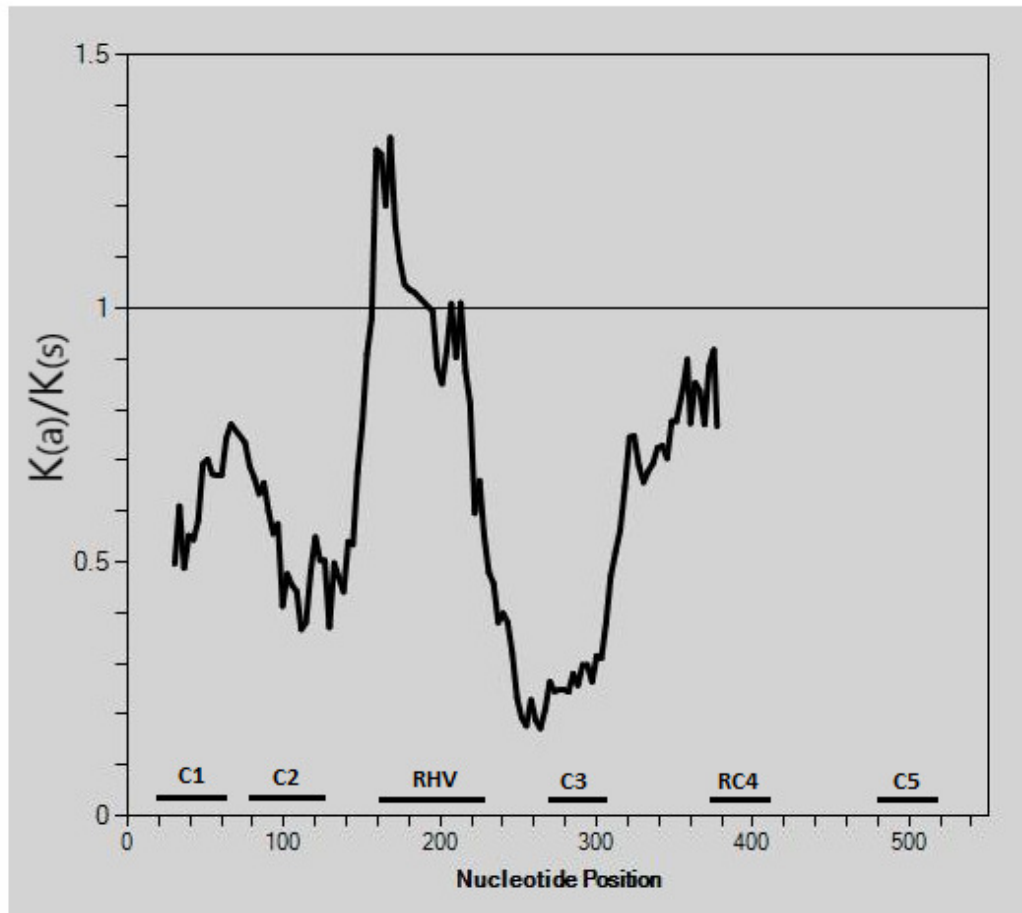


Figure 3

PCR amplification of the $P$. serotina $\mathrm{C} 2-\mathrm{C} 3$ intragenic region using the Ps1C2Fw and Ps2C3Rv primers.

Black arrows indicate the position of the expected alleles whereas white arrows highlight the unexpected alleles obtained for H25, Azu15, Pic19, Car7, Car3 and Car12 

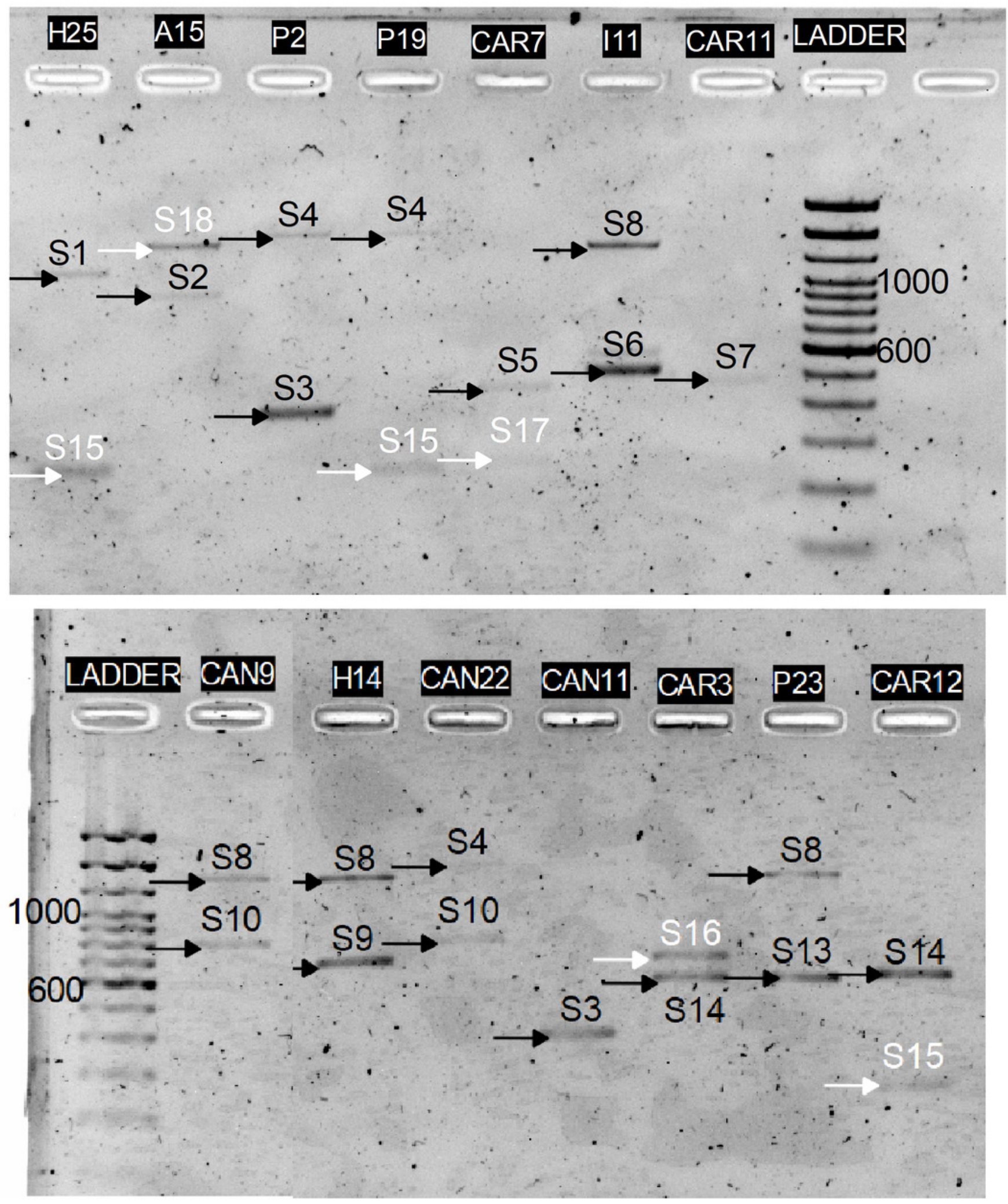
Figure 4

In-vitro CAPS patterns obtained for alleles $\mathrm{S}_{1}, \mathrm{~S}_{3}, \mathrm{~S}_{4}, \mathrm{~S}_{5}, \mathrm{~S}_{6}, \mathrm{~S}_{7}, \mathrm{~S}_{8}, \mathrm{~S}_{9}, \mathrm{~S}_{10}, \mathrm{~S}_{12}, \mathrm{~S}_{13}, \mathrm{~S}_{14}, \mathrm{~S}_{15}$, S[sub]16

Letters indicate the restriction patterns reported for each enzyme in Table 1: Rsal, Mbol and Hinfl, respectively 

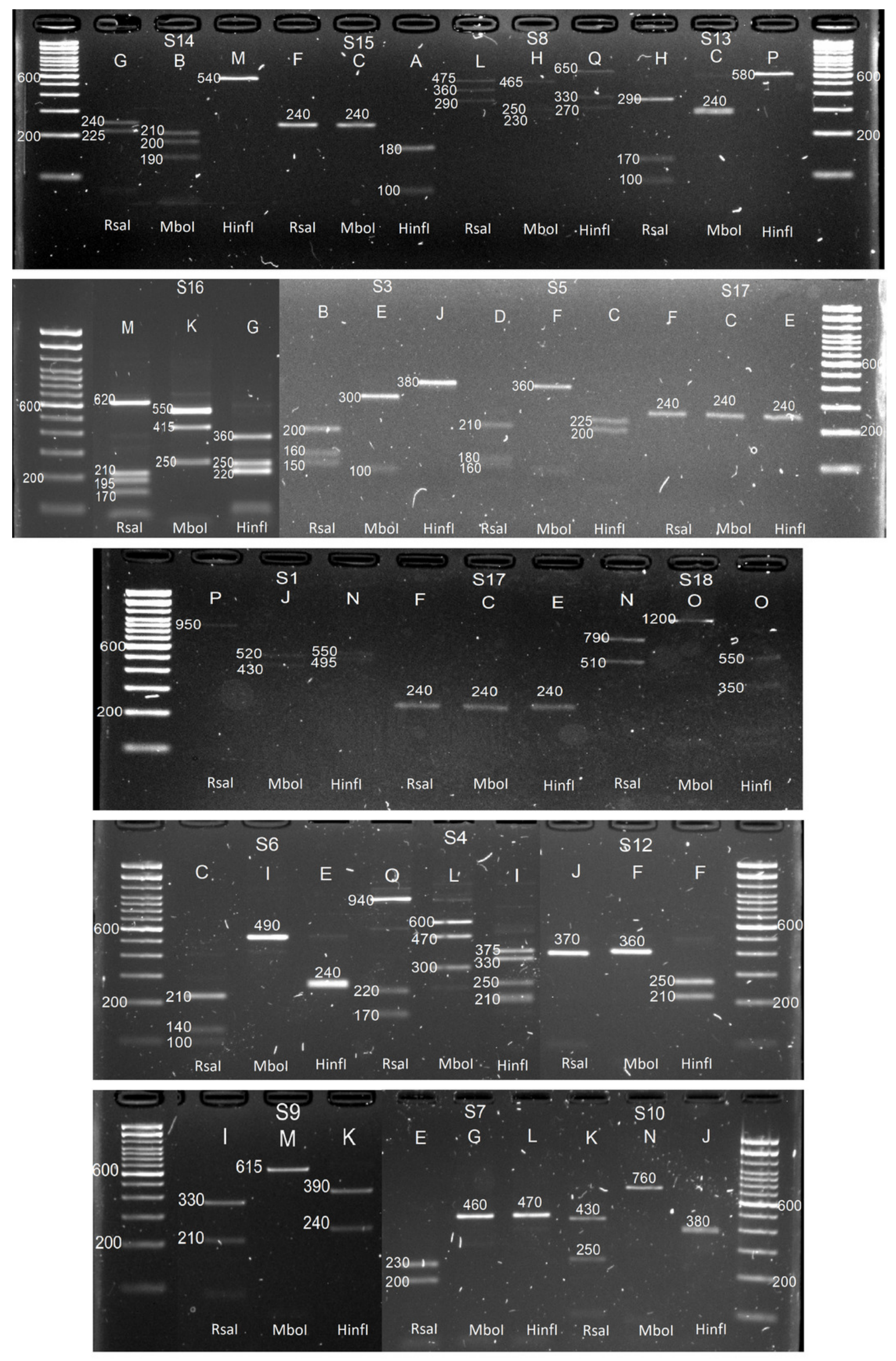


\section{Figure 5}

Pollen tube growth analysis in incompatible and compatible assisted crosses using fluorescence microscopy.

Pollen tubes were stained following the aniline blue protocol after 48 hours of hand pollination. A) Compatible cross: Individual $17\left(\mathrm{~S}_{1}-\mathrm{S}_{4}\right) \mathrm{X}$ Individual $1\left(\mathrm{~S}_{8}-\mathrm{S}_{19}\right)$. Pollen tubes grew along the style and reached the ovary. Pollen tubes growth was inhibited in the upperthird section of the style showing swollen tips. B) Incompatible cross: Self-pollination of Individual $1\left(\mathrm{~S}_{8}-\mathrm{S}_{19}\right)$. Pollen tubes growth was inhibited in the upper-third section of the style. C) Swollen tips of Self-pollination of Individual $13\left(\mathrm{~S}_{4}-\mathrm{S}_{9}\right)$

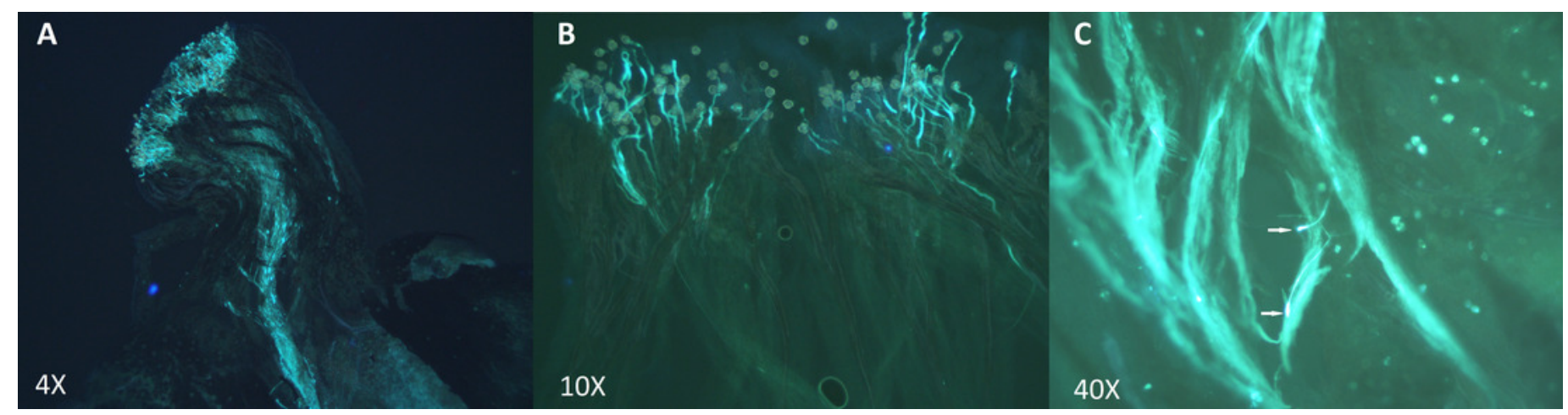

